\title{
[7]
}

\section{Aesthetics of Leisure}

This chapter deals exclusively with leisure activities that take place away from home and are not associated with the church. Leisure at home is covered in Chapter 4, leisure connected with the church in Chapter 6 . There are three other broad classes of leisure: hunting and fishing, informal associations, and formal associations. All three are male-oriented, and the aesthetics involved are frequently conducted with an air of privacy or secrecy.

Any local man who does not hunt or fish is considered an oddity. These leisure activities are the pride of Marsh County, and the area is nationally renowned for them. Although both hunting and fishing are immensely enjoyed, hunting involves more public display. Gun racks, decoys, wildfowl pictures, and trophies adorn many living rooms, whereas fishing tackle is relegated to the garage or the barn. Furthermore, the single most common sport for home exhibit is duck hunting, considered the traditional sport. All local men who are able will go "ducking" at some time during the season, and for many their passion borders on obsession. The aesthetics of this sport are subtle and potentially misleading to the outsider. What appears largely functional, such as the look of duck blinds and decoys, turns out to be more aesthetic than pragmatic.

By late October most talk among men in the community concerns the upcoming duck-hunting season: who is preparing blinds, where to get materials for blinds, new shot cartridges on the market, and so on. At the same time preparations are in full swing. Earliest attention is paid to blinds from which hunters shoot.

Local men distinguish four kinds of duck blind: bush, point, marsh, and float. The first three are built on much the same principles, differ- 
Figure 58. Bush blind

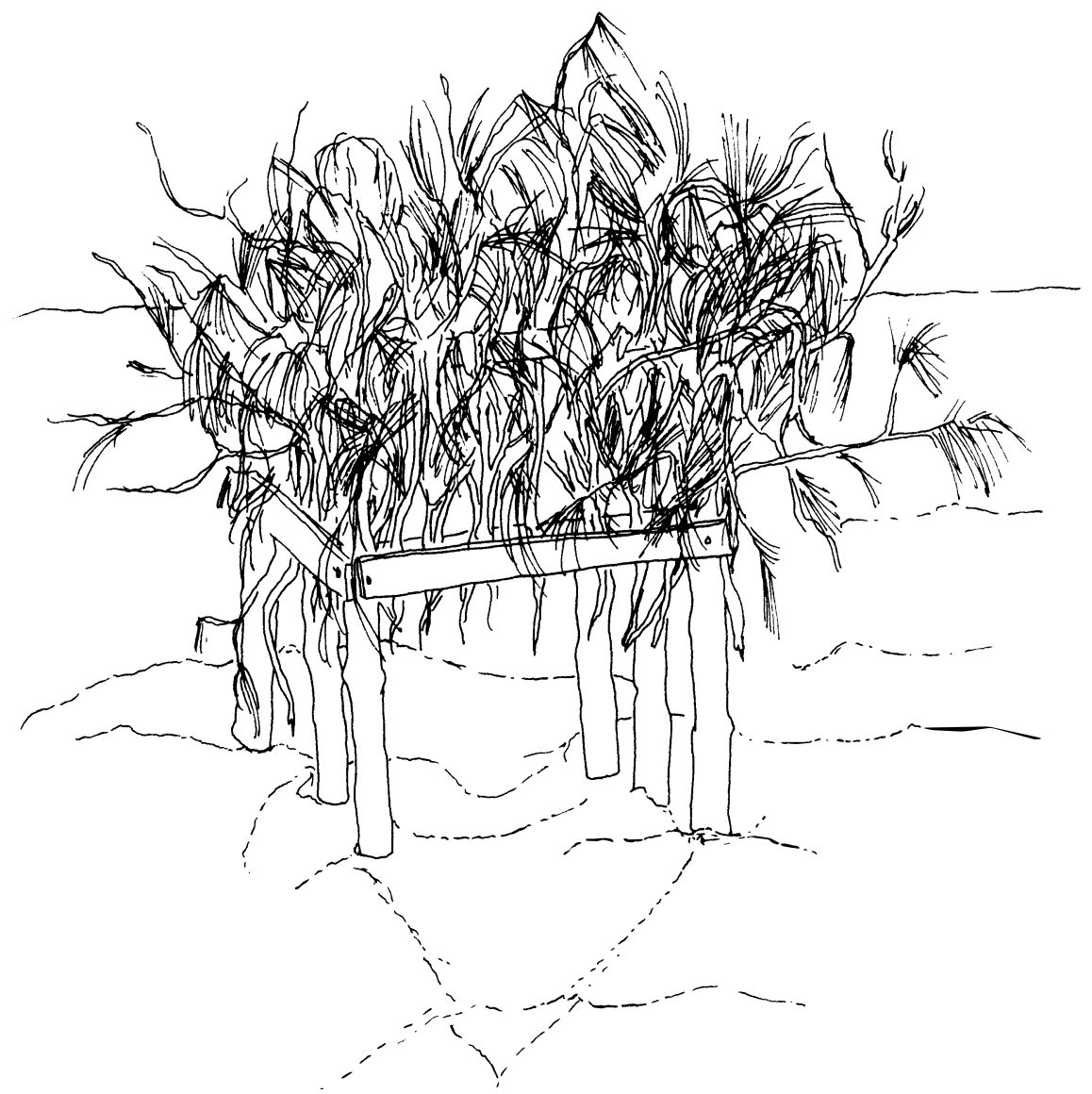

ing only in location, the fourth is fundamentally different. A bush, point, or marsh blind is essentially a box six feet by three feet and four feet high, with a door in one of the long sides. The hunters drive four stout juniper poles into the mud to support the box about one foot above the waterline. The box is secured to these poles, and the whole construction is surrounded by cut pine saplings. Bush blinds are located in the sound in water about five feet deep (see Figure 58). In many cases the hunters build a boat blind adjacent to the box to hide the skiff they will use to get to the blind. The boat blind is a boatshaped frame to support more saplings that will surround and conceal the boat.

Marsh blinds are located on the edge of marsh ponds. A boat may 


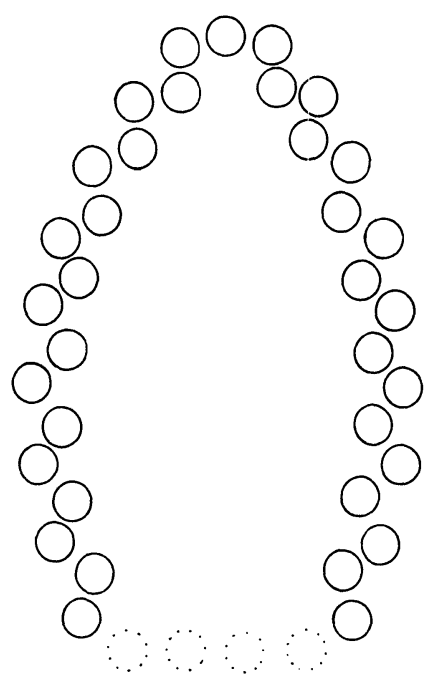

Figure 59. Boat blind scheme

KEY

Fixed sapling

Movable sapling

still be needed to get to them, but stowed at a distance from the boxin this case the boat blind is simply a hedge of saplings stuck in the mud. Such blinds may also be used in lieu of a box, to hunt from. In this instance the boat itself serves as shooting platform (see Figures 59 and 60). Point blinds are built on the points of the shoreline and may have either an adjacent boat blind or one located at a distance, depending on the ease of walking on the shore.

A float blind is nothing more than a skiff with a temporary frame to hold small saplings attached to the washboards. The hunter drives the skiff to a suitable location and anchors. Then he pushes pine saplings into holes in the frame to surround and conceal the boat. Hunting is done from the boat itself and is carried out in parts of the sound where the water is too deep for a bush blind (Figure 61).

The term "bush blind" strictly refers only to blinds built in the open water of the sound, but all of the blinds described above are "bushed," that is, camouflaged with pine bushes. This choice of materials is noteworthy because the effect, to the outside eye, is decidedly odd. The marshes in mid-November are mostly pale brown where the grasses have turned color. A marsh blind bushed with green pine boughs is visible from a great distance. But the hunters as they bush their blinds seem oblivious to this observation and constantly assess their handiwork, visually checking with each other on the naturalness of the look of the bushes. Their greatest concern is to hide the "human look" of the box, which by their lights means right angles, straight 
Figure 60. Boat blind

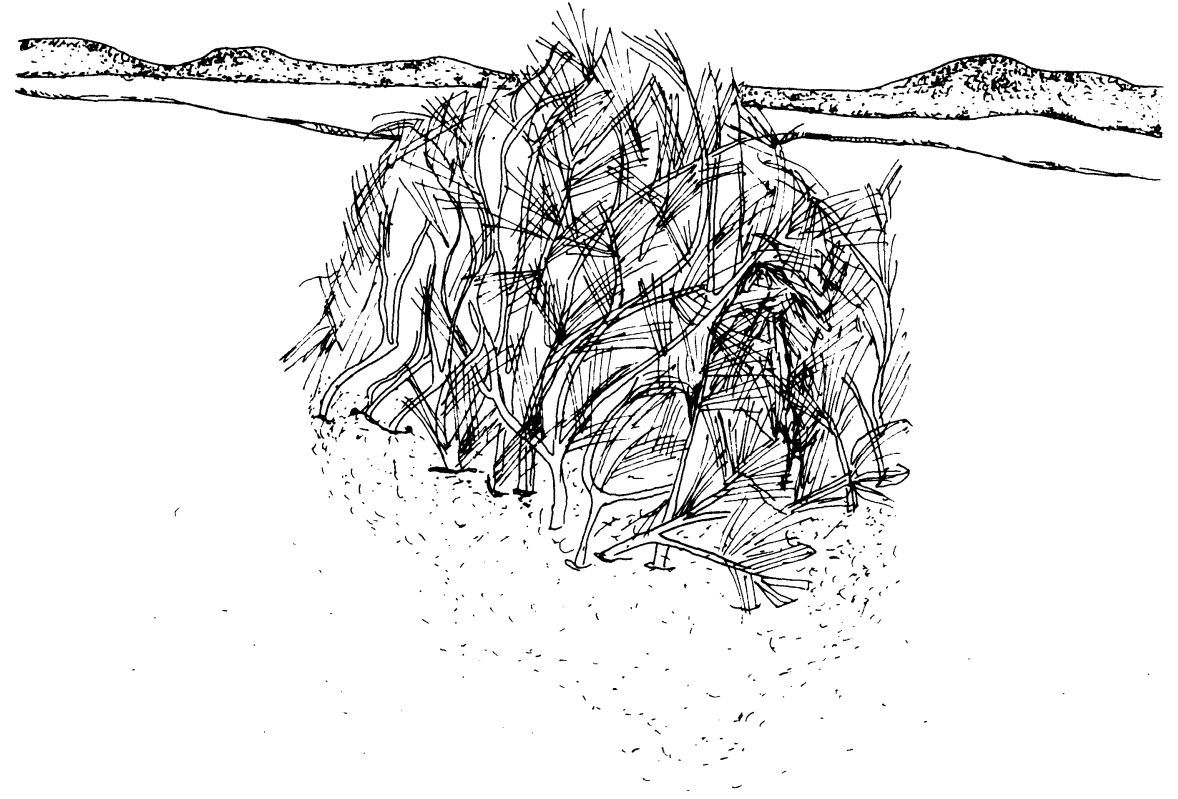

edges, and raw cut wood. These all look unnatural, whereas pine boughs, regardless of their location, look natural. Because of the normal reluctance of the waterman to fool around with the natural environment, this process struck me as odd at the time and led to conclusions concerning the aesthetic nature of ducking. I return to those conclusions after considering another aesthetic aspect of the hunting environment: decoys.

Having repaired or built and bushed his blind the hunter turns his attention to his rig of decoys. No one in the area makes decoys now, but most hunters still use hand-carved wooden decoys made at the turn of the century by market hunters. The aesthetics of the decoy itself is of considerable importance in understanding the general aesthetics of duck hunting.

All hunters will admit they do not think a decoy has to be lifelike. The following statement is typical: "You could paint every one of them a grayish black, every one of them a grayish black, and not put no other color on 'em, and I swear stuff'd come to 'em just as good. Doesn't make no difference. I've took cow manure-it was cold and dry -in the winter time, and set 'em out on the edge of the ice, and had just as good shooting as I ever had in my life." Other older hunters 
Figure 61. Float blind

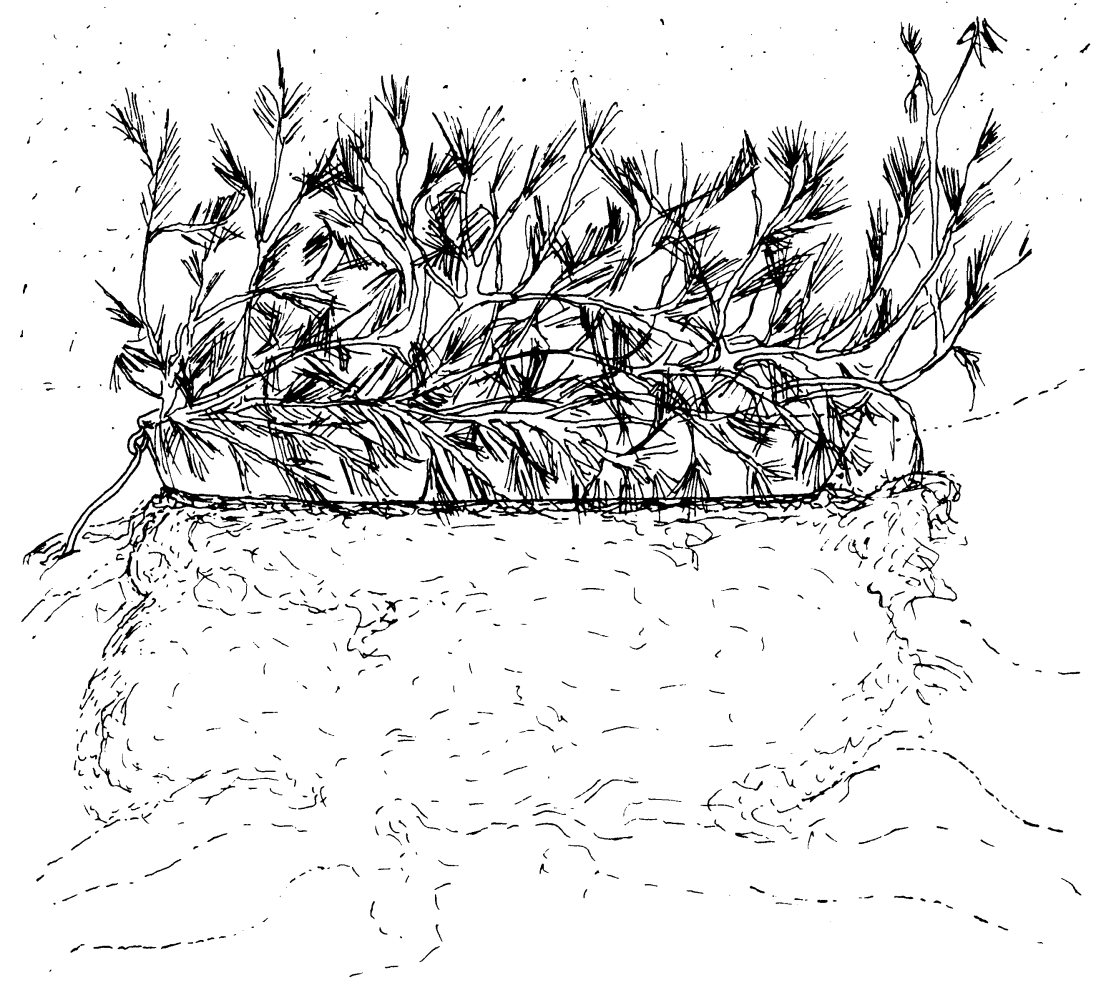

spoke of the practice of "turfing out," that is, wedging lumps of sod in cleft sticks as rough decoys. And modern hunters make snow goose decoys by filling white trash pail liners with dirt. Even so, contemporary hunters keep their wooden decoys freshly painted to resemble various species of ducks. They are also very particular about having their rafts of decoys resemble as closely as possible a raft of feeding ducks. At the outset, then, it is fair to speculate that the decoys serve primarily an aesthetic function.

Most local carvers took some care to make their decoys resemble ducks, and some were quite remarkable craftsmen. But as the market 
hunters had to keep a raft of between four and five hundred decoys in working order, the carver could not take too long on any one decoy. One hunter described a turn-of-the-century carver: "He made the roughest, outlandish decoys there was made in Marsh County, I believe. But ducks would come to 'em. He could kill ducks with 'em. He just knocked the corners off a block of wood and rounded up a little bit, and nailed a head on it. And it didn't make any difference what size head it was." Even though "ducks would come to 'em," this hunter added: "I've got a few of his decoys here and I expect to work 'em over with a spokeshave and make 'em a decent decoy." A "decent decoy," in other words, is one that looks good to the hunter, not one that is noted for attracting ducks.

Almost all of the wooden decoys still in use are painted to resemble one of three species: canvasback, redhead, and widgeon. During the market gunning days canvasback and redhead were prime ducks, fetching up to seven dollars a pair. It takes little artistry to paint a decoy to resemble a canvasback or redhead, and the broad splash of white on the back makes the decoys show up well. Market hunters so depleted the flocks of canvasbacks and redheads that it is now illegal to shoot them, but, nonetheless, hunters still use the decoys. The widgeon decoy was made more for sportsmen than for market hunters. The complexity of its markings shows how much of a part the hunter's aesthetic preferences play. To paint a redhead is simplicity itself (Figure 62), and touchup at the beginning of the season requires little effort. By comparison the widgeon is complicated to paint and difficult to maintain (Figure 63). For this reason it did not find favor with the market hunters. Some widgeon decoys are even more elaborately painted than the one in Figure 63, with white bellies or a patch of black on the wings. All of this decoration is done even though the hunter knows that a lump of grey wood will do the same job.

Market and early sport gunners did not use goose decoys because they were cumbersome and the long neck was easily broken. Modern hunters on the sound use a small raft of goose decoys in conjunction with their duck decoys. They say the whole scene looks more peaceful and inviting. Most of these decoys, made in the 1940s and 1950s, are of wire-frame and canvas construction (Figures 64 and 65). The decoy maker begins with an elliptical wooden base and attaches a series of wire hoops to it, over which he stretches the canvas body. Finally he carves a head and neck from juniper and nails it on. The whole may be painted to resemble a Canada goose or a swan. These frame decoys are lighter to handle than solid wooden ones. Again, the decision to use 


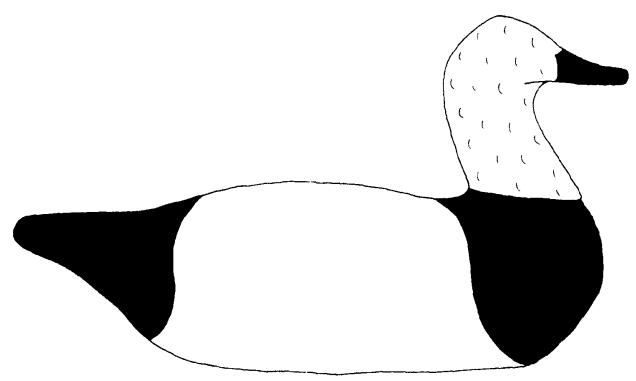

Figure 62. Redhead decoy

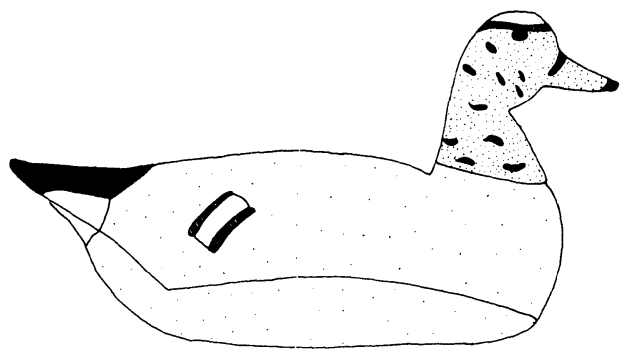

Figure 63. Widgeon decoy

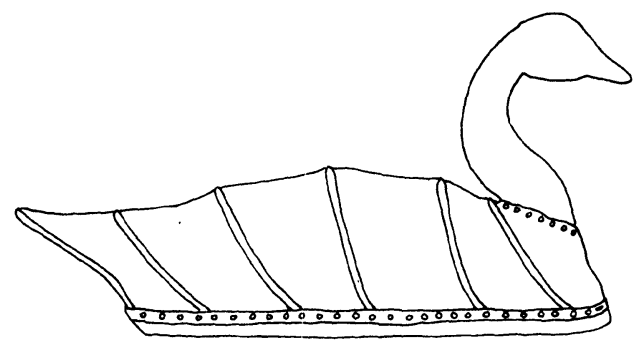

Figure 64. Goose decoy frame

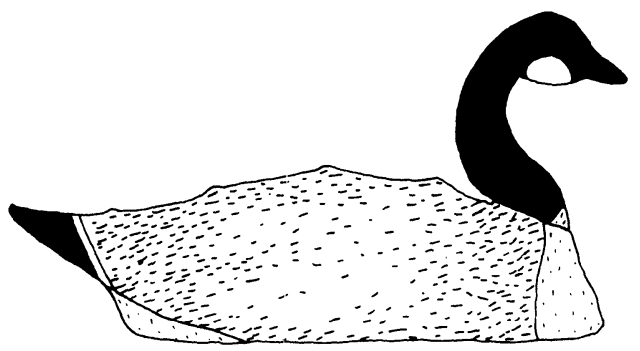

Figure 65. Frame Canada goose decoy

goose decoys at all is primarily an aesthetic one. The hunters feel that goose decoys give the raft a natural look, yet they also claim the wildfowl cannot identify the species of a decoy until they are within firing range.

Most modern hunters have some plastic decoys in their collections. 
Hunters who wish to hunt the marshes buy a few mallard and ringneck decoys for use there. Canvasbacks and redheads do not frequent marsh ponds, and hunters feel that rafts of this type of decoy in a marsh setting would look unnatural. Market hunters had no use for marsh duck decoys because they hunted exclusively in the sound, where the high-priced ducks flew. As a consequence there are no wooden marsh duck decoys for modern hunters to use. Modern hunters have no objections to plastic or rubber decoys, which are light, do not need painting, and look realistic.

A few weeks before the season opens the hunter makes sure he has a sufficient number of decoys in working order. He touches up worn paint and replaces frayed weight lines. He may need only twenty to thirty decoys per location, but if he hunts in both the marshes and the sound he may need as many as fifty duck decoys plus some geese so he will have sufficient numbers of the species appropriate to the different locations. He also needs a few spares, because he will not have time for running repairs once the season is under way.

The day before the season starts sees the most energetic preparations. Decoys must be sorted and stacked in the hunting skiff's bows, where they will be stored when not in use all season. Guns are given a final check to make sure they are clean and in good working order, and shells are packed in ammunition boxes. The younger men can hardly suppress their excitement as they make ready, whereas older hunters affect a casual air. The next day, first day of the season, is often the best day's hunting all year. The ducks will not have learned to be wary and can be expected to come to blinds easily. As the season progresses they are harder to deceive, and daily bags are slimmer.

The hunting party sets out for the blind at about thirty minutes before sunrise, so as to be set up and ready at sunrise, the legal start of the day's shooting. Upon reaching the blind the hunters throw out their decoys. Each hunter has his own theories about the positioning of the decoys in rafts, but most end up bunching them in loose rafts directly in front of the shooting platform of the blind, with goose decoys, if used, rafted upwind from the ducks. For a float rig, the geese are rafted at the bow and the ducks at the stern. Most hunters are aware of more "scientific" placements of the decoys, such as the one in Figure 66, but few bother with them (several men owned the book and showed this diagram to me). It takes a good deal of time to place the decoys in this manner, which also demands that the decoys be stored separately in a way that is impracticable in a small skiff. What is more, these placements do not mirror natural rafting behavior 
Figure 66. "Scientific" decoy placement (after Walsh 1971:12)

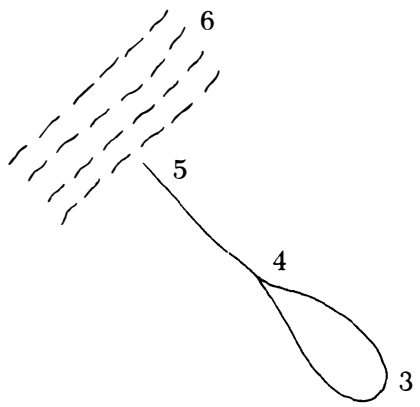

7

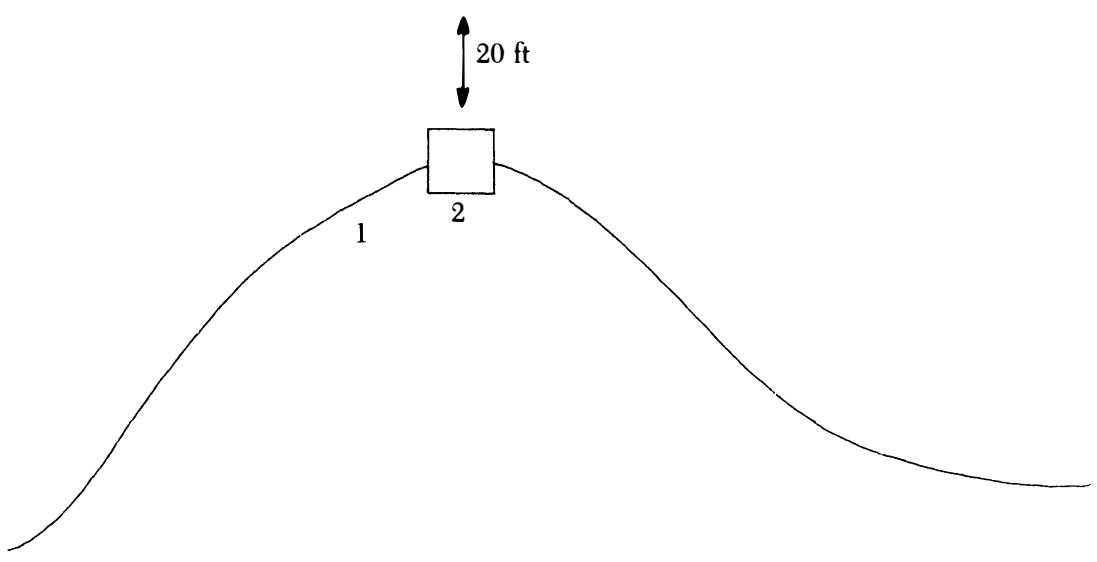

1. Point of shore

5. Stringer

2. Shore blind

6. Oversized decoys

3. Head of decoys

7. Wind direction

4. Tail of decoys

so that, whether they work or not, they do not look right to the hunter.

With decoys set up and boat stowed, the hunters prepare themselves. Normally two men hunt together, although most blinds can comfortably accommodate three. Men who hunt together are old friends who enjoy each other's company as much as the hunting itself. During slack times they exchange hunting stories, discuss current conditions, and so on. Even when nothing is flying about they still keep their eyes on the horizon. Their ability to spot and identify ducks at a great distance is an important skill.

To a novice glancing through a manual on field identification, it may seem an easy matter to tell species of ducks apart. With a few excep- 
tions the coloration of drakes is distinctive and, one might imagine, makes identification on the wing a simple matter. But in fact, until a duck comes within short firing range its colors barely show. The observer may catch a glimpse of white on back or wing, but usually he must rely on more subtle signs.

The three keys to field identification are silhouette, flock pattern, and flight pattern. Some examples of this kind of identification show the visual acuity necessary. Canvasbacks travel in lines or Vs when migrating and in compact flocks when flying over feeding grounds. They fly very fast with a rapid wing beat. They have a large, plump body, flattish neck, and long beak. Widgeons fly in open flocks, constantly twisting and turning. Their bodies are medium-size and slender, and they have short beaks. All mergansers fly in straight lines low over the water. They have long necks, which they stretch out straight in front of their bodies when flying. In Marsh Sound the gunner will see all three species but is interested only in the widgeon. It is illegal to shoot canvasbacks, and locals consider all fish-eating ducks, such as mergansers, inedible.

When the hunter has identified a small flock as legal and edible he may use calls to lure it closer. Whether to use calls is a subject of some controversy, and the general feeling in Tidewater is that one should either be an expert with a call or use none at all. The sight of a tourist hunter at the local stores with a duck call hanging from the zipper of his hunting jacket usually calls up a knowing smile from residents. Tidewater men will feel that such a "foreigner" probably frightens more birds with his call than he attracts. The duck call is supposed to complete the illusion that the decoys are a peaceful raft of ducks feeding contentedly, but in the wrong hands it can destroy the whole deception.

If a flock looks as if it is getting ready to "decoy," the hunter gives a few greeting calls: a loud qu-a-a-quack-quack-quack, followed by a feeding noise: a low k-k-k-k-k-k-k. (Some hunters do not use calls but produce an array of honking and quacking sounds using their voices.) When the ducks come within range the hunters stand and fire. If the ducks do not decoy, particularly if they veer away at the last minute, the hunters discuss the cause of this behavior. Discussion almost always turns on what in the scene does not look natural enough.

A neophyte might be forgiven for thinking that these men believe that a lifelike scene around their blinds is what attracts ducks. Certainly they are at pains to create what they consider to be a natural setting. But there is another, less mysterious, reason why ducks come 
to the blinds: they are baited with corn. This practice is illegal. A baited blind attracts large numbers of ducks regularly, as every hunter knows, but most hunters are afraid that without bait they will have no ducks. It is difficult to avoid the conclusion that decoys, calls, and so on are part of an elaborate staging for the hunters' benefit.

It could be inferred from this elaborate seeming hoax that hunters have found a way to indulge aesthetic fancies without appearing to do so. They can claim publicly, with some authority, that all of their blind making, decoy painting, and quacking serves a practical function, yet on the sly they will not hesitate to reveal how unfunctional it all is. As an aesthetic form the act of hunting is multisensory, involving the sight of the natural environment, wildfowl, blinds, and decoys; the sound of real and imitation ducks and geese and the powerful explosions from shotguns; the feel of cold blasts of winter air, icy rain, and sleet; the fetid smell of the marshes and the acrid smell of gunpowder; and the anticipation in long narratives of the taste of duck. Such an aesthetic performance might well be the subject of men's passions.

Duck hunters never hunt alone. Passionate or not, the hunter who cannot find a partner for the day will not go out. If duck hunting is a performance, it is one that requires an audience. The lone hunter has no audience, and in consequence the pleasure and meaning of the act are absent. In addition it is de rigueur to recount the day's events at the general store in the evening, and it is considered immodest to tell of one's own fortune's (although one may recount mishaps). It is the task of the partner to extol one's skills.

Locals consider all other forms of hunting to be second-rate in comparison with ducking. These forms tend to be relegated to boys and "foreigners" or are indulged half-heartedly when duck season is out. None of these secondary forms of hunting has the aesthetic accouterments of duck hunting, nor do they carry the prestige and weight of tradition. Furthermore, their goals are pragmatic: they supply meat. Each of these sports attracts men and boys who like the taste of the game they hunt. No aesthetic elaboration obscures this relationship.

The basic idea behind deer hunting is simple. Before the season opens in mid-October the hunters watch the woodlands beside bean fields at dusk to see where deer are feeding. They also keep an eye out by day for spoor, rubbed bark, and other signs of the presence of deer. When the season opens, and having gained the requisite permission from the landowner, a band of hunters hunts a stretch of woods. If the woods are completely on dry land the hunters position themselves 
individually around the woods in concealed spots that offer a wide field of vision. When all are ready one member of the gang takes five or six deerhounds into the woods and turns them loose when they pick up a fresh scent.

A good deerhound remains silent while searching for a scent and when he finds one sets up an intermittent bark. If he catches up to a deer and pursues it, he will howl continuously. The hunters on their stands strain constantly to hear the hounds and to determine what they are doing and in what direction they are traveling. Most commonly the dogs run for an hour or two, barking on occasion as they catch a scent but ultimately failing to flush anything from cover. In this case the dog handler rounds up the dogs, and they move to a new set of woods to begin again.

When a deer is shot it is tagged and registered. Next the carcass is hung from a tree limb and skinned, gutted, and butchered. This operation is carried out with great excitement, most of the banter focusing on how each hunter will cook his allotted portion (all members of a hunting party share in the kill). The flesh is butchered very much like a carcass of beef but with fewer divisions. Shank, rump, and round are taken as one cut, as are rib and plate, and chuck and brisket. The hounds get the offal as a reward and to reinforce the taste and smell of deer. Someone may take the heart and liver to make a hunter's stew, but this practice is now rare.

At the end of butchering the hunters divide the meat. The hunter who actually made the kill gets first choice. He takes either the sirloin or one of the rump/round roasts. Next a choice piece is set aside for the owner of the land on which the kill was made. Then those who made special contributions to the hunt, such as providing dogs or transportation, make their choices. The remaining hunters then choose from what is left. Preferences generally are for hindquarter cuts first, then forequarter, then ribs.

No one goes deer hunting who does not enjoy the taste of deer meat. The final pleasure of the hunt is to sit down to a supper of roast, broiled, or barbecued venison. Younger men and boys often reserve a whole carcass for an outdoor barbecue party. In this case they openroast the meat on a rack above a slow flame in much the same way that a hog is cooked at a pig picking in other parts of the South. The roast meat is served with a hot barbecue sauce and appropriate trimmings, such as potatoes and coleslaw.

When the duck season provides poor hunting, or between seasons, some men take to field hunting. Animals hunted include dove, squir- 


\section{Lord I'm Coming Home}

rel, rabbit, raccoon, and quail. These kinds of hunting have few devotees, mostly boys and a few newcomers to town.

To hunt dove a group of men (any number) sit singly along a known flyway in a corn or bean field. They fire as doves fly within range. Although the hunters are in solo positions, they are not isolated like deer hunters. Each can see all of the others at all times and observe the overall pattern of the hunt and the activities of the birds. Doves may be hunted from noon to sunset, but most hunters do not care to stay out longer than an hour or two. At the end of the hunt the hunters compare bags. Those with one or two give them to those with larger bags to form "messes," that is, enough for a family meal.

Squirrel hunting is definitely a boy's sport, and men consider it to be important training in marksmanship. Hunters despise poor marksmen for a variety of reasons, but perhaps the most important is that the "sorry shooter" cripples many animals that then crawl away and die in hiding. Men prefer to kill an animal with the first shot or not shoot at all. They also hate to see animals suffer or to loose cripples.

Squirrels are hunted by single hunters or by pairs. The hunter quietly positions himself in a wood where he has seen squirrel activity and waits for a shot. This kind of hunting teaches boys to be patient and quiet, to select only good shots by properly gauging distance and angle, and to judge their own skills. Squirrel hunters use .22 caliber rifles, considering anything larger to be unsportsmanlike. Raccoon hunting is similar except that it is done at night with the aid of lights, because raccoons are nocturnal.

Rabbit and quail hunting reach peaks of considerable sophistication and cooperation between man and dog in many parts of the South, but in Tidewater the sports are haphazard and largely confined to newcomers. The simplest way to hunt quail and rabbit, often at the same time, is to send a flushing dog into thickets and brier patches on the margins of arable fields. Sooner or later something will fly up or out and provide a shot for the hunter. Local men consider this very poor sport and hardly worth the effort.

In spring and summer Tidewater men devote their leisure energies to fishing. For many fishing is the ideal way to spend as little or as much time and effort as one wishes. Men may go out into the sound if they have enough time, but many are content to fish in ditches or on the river bank. Freshwater fishing is universally popular, but most men make one or two expeditions to the beach each year for some surf casting. In both cases the pleasure resides in a good battle with the fish. Largemouth bass provide the best freshwater sport, bluefish in 
saltwater. The primary difference between freshwater and saltwater fishing is that the former produces little in the way of "edible" fish whereas all saltwater fish are considered edible.

Local freshwater fishermen toss back bass (too strong), pike (too bony), and panfish (too small). The only fish they routinely keep are "rock," that is, striped bass, because they are highly prized by local cooks. The joy of freshwater fishing resides in being out of doors near water and putting up a challenge to nature. Many consider the challenge especially satisfying because no permanent harm is done to the fish. They also despise and ridicule out-of-town fishermen who keep (and eat) everything they catch.

Surf fishing is less common because it requires time and energy to get to the beach and get set up. However, the culinary rewards make the effort acceptable from time to time. All saltwater fish are considered edible: drum, flounder, croaker, spot, and bluefish. But the bluefish alone provides the sport that justifies catching other varieties of fish. One local compared catching a flounder to landing a dishrag, but a bluefish is a different story. It may bite the line, jerk up and down, run up to the beach and shake violently, in fact do almost anything to free itself. This kind of challenge provides the main reward for fishing at the beach.

For many men in Tidewater the day's sporting activities are not complete without a trip to the general store to give an account of adventures and mishaps and to hear the same from others. Two quite distinct groups meet at the stores: youths and retired men. As younger men get married and have children they drift away from the "store crowd." Their time is taken up with family matters, and many work both days and evenings. But when a man retires he finds he has time on his hands, and slowly, reluctantly at first, he returns to the store. At the beginning of my observation year a well-respected, hard-working man retired from a city job he had held for thirty years. Throughout the year he was ambivalent about retiring and would periodically take on small jobs from his old employer. At the same time he began to get moderately involved in gill net fishing and was seen more and more frequently hanging around at the store. His kin were surprised to see him at the store because he is stubborn, and joining the store crowd is an open admission of old age. By the end of the year he was a regular at the store, and at the same time he bought the materials to make eel pots. This final act severed him completely from employment, because eel pots need daily tending.

The meeting of youths and old men at the store is a microcosm of a 
much greater unity between the two. Youths and old men share much of the same work and leisure habits and have similar outlooks on the world. Both regularly hunt and fish for pleasure and take only intermittent employment. They enjoy informal associations such as the store crowd and prefer to come and go as they please. Both groups are often characterized as "roosters" or "pistols," meaning that they are generally unbridled. However, the older men have a different status from the youths.

A senior adult may buy a few gill nets or crab pots to earn a small supplement to his other sources of income, and he may take on a youth, especially a family member, to help. But because he owns the equipment, and because he has a great deal of experience, the senior adult is definitely in charge. At the store the senior adults are the raconteurs, and the youths sit and listen or provide prompts for the older men to continue storytelling in a certain vein. Although older men return to the activities of their youth, activities they had to forego in their middle years, they assume a higher status when they return.

Men hang around the store all day, but it is after supper that the most active sessions occur. Generally by seven o'clock three or four men are present with a handful of boys, and talk wanders across topics of general interest. Whenever a known storyteller shows up the general flow of conversation slackens, and he is given the opportunity to amuse the crowd. A good storyteller is generally allowed to proceed at his own pace, without interruption, and to tell as many stories as he likes. But if two happen to meet, they may trade stories with everybody else looking on.

Samples of stories and exchanges give a broad sense of the ethos of storytelling and "shooting the bull" at the store. The first story is, like most, a segment of local history, and I have chosen it for extended review for several reasons. First, and perhaps most important, I have two versions of the tale told by the same man, which allows careful comparative checking of conclusions concerning narrative structure and performance style (the second version appears as Appendix B). Second, the tale contains many narrative and performance elements that are common to all local tales.

Following leads from the literature on ethnopoetics (Bright 1980; Hymes 1976, 1977; Tedlock 1971, 1977), I have transcribed the tale in a way that makes manifest some basic elements of narrative and performance structure. A complete list of my transcription conventions appears in Appendix B, but they boil down to a simple rule of thumb: an untabbed line break or a conventional punctuation symbol indi- 
cates pauses in the narration. I have ordered the lines so that each begins with a particle, usually "and," because repeated listening to the tapes has convinced me that they mark segments of the narrative structure. The narrator commonly paused at the end of a thought or flow of ideas, said "and," often paused again, then added a new element to the narrative. Comparison of the two versions shows that similar narrative elements are framed by particles and pauses in both and confirms the general validity of this approach. I have also divided the lines defined by particles into couplets, again because analysis of the two versions appears to warrant it. The units of meaning in the couplets seem to belong together. But I have not been completely reductive in this regard. Some segments cannot be paired into couplets and so have been put into suitably longer or shorter units. Nor do I make any assertion that this narrative is poetry, nor adopt the theoretical perspectives of ethnopoeticists wholesale. Such claims are outside the bounds of the present work.

And, I . . was a fellah buried on Tate's Point that was . . . died in eighteen, and forty eight

And his name was Wallace Tyler-he had a son named . . . HarryHarry Tyler

And of course when the old man died he left the place, there

And was six thousand acres of that property

And was all timber was good timber

And this was a point of land, with a creek in back of it, two miles long-in another county it is now

And he used to make sailing vessels

And trade with the West Indies [*]

And he had a hundred slaves on Tate's Point-he couldn't always said he couldn't keep a hundred-this is things I've heard-he couldn't keep a hundred just as soon as he got a hundred one of them would die or something would happen to one of them

And he never could keep quite a hundred slaves.

And, he built ships up that creek

And I did know the name of - three he had three-

And, what the way I understand it this is . . . fact with maybe some fiction into it or maybe some . . . warping of the truth

But the way I've got it from . . . three generations back, that, Wallace 


\section{Lord I'm Coming Home}

Tyler was in Baltimore harbor, about the turn of the seventeenth century - not the eighteenth century but the seventeenth; he was in Baltimore harbor about... seventeen, and four-somewhere around seventeen and four.

And there come what they call a Baltimore . . . waterfront fire; it wiped out . . . the docks, with a hard north . . . west wind, from what I've understood.

And it would just sweep right down . . . the waterfront-it was cleaning the houses out.

But he had a schooner tied up to the dock.

And they just moved his schooner back they traded in them days . . . in gold and silver-paper paper money was nothing

And, all these traders

And, Baltimore harbor was always a trading center-they just moved this schooner down . . . the docks . . . as the fire forced them to

And took their safes

And strongboxes they had their silver in and their gold;

And took it and put it aboard this schooner,

And moved along - take the next one take the next one;

And when he got loaded . . . with strongboxes - the wind was to the west'ard-he just pushed off from the dock and set sail-it was at night-

And set sail down the Chesapeake and he had a fair wind,

And perhaps a strong one,

And when it come daylight he was gone.

And, of course he came ... on ... down the Chesapeake and come on out the Chesapeake-mouth of the Chesapeake

And the first inlet . . . that you could get in south of the Chesapeake, in them days, was possibly ... Cooper's Inlet, which was about three . . . three to four miles north from Tate's Point Creek

And I . . . from what I understand he run in that inlet with this boat And went in that creek and up in a place called Gum Cove with about six feet of water - six to eight feet of water and mud-he got afraid the revenuers would run him down-he dumped all these safes overboard, strongboxes and stuff overboard in-in . . . Tate's Point Creek.

And, he stayed around, see what was going to happen and nobody didn't bother him 
And so he got-took these safes up-went overboard and dove them up or whatever he can, may be some of them in there yet.

And, of course he had money then

And he bought this . . . property-six thousand acres of it.

And this . . . point of the land known as Tate's Point is . . . in that . . . six thousand acres - this creek is in that six thousand acres, Tate's Creek's two miles long,

And he carried on a trade with the West Indies.

And the war come in; he died; his son took over-you could still have slaves - so he took over his daddy's slaves

And got more

And Harry-not Harry but... Hyram ... not Hyram, Harry's child-Harry is the one-he took over from his dad

And, run the place, till the war come on between the states;

And when . . . he could see that the war was coming on between the states, he got his three vessels . . . in . . . inside . . . from the West Indies $[*]$

And got them in and got them in Tate's Point Creek

And he had a railway there for pulling them out and

And, cleaning them-cleaning them and painting them

And I've seen the railway-it was still . . . visible when I . . . lived there

And, when the war come on, he had all his vessels in there

Well, Burnside come up, from Hatteras, from inside and started to clean up . . . the sounds and clean up the boats $[+]$

And .. . take over this section of country

And, when he come up there to Harry's Harry knew he was cominghe had a boatload of nails, bound for the West Indies

But he couldn't get her out

So he run her out out of the creek

And tried to . . . run her into Whiskey Creek which is on the other side of the sound, about four miles

And take the masts out of her-with the intention of taking the masts out of her

And covering her with . . . trees up that creek to keep the Yankees from burning her up 
But they caught him in the middle of the sound

And burnt him up

Course he weren't aboard if his captains were

Then they went ashore at Tate's Point

And he had took his gold and silver

And supposedly put it down a well, at Tate's Point, in brass boxes he had had it in brass boxes-put it down the well:

And when the Yankees come there to get him they knew he had gold and they knew he had silver-cause he was a trader

And, they beat him nearly 'bout to death to try to get him to tell where it was $[*]$

And he wouldn't

And he didn't

And that was around eighteen and sixty ... three,

And he . . . I've never been to look at his tombstone

But I don't think he lived more than four or five years after it I think they beat him up so bad-he didn't live long

And, that's where all the Tylers down at the south end of this-Marsh County - this peninsula down here-that's where all the Tylers come from-that's where the name Tyler came from there's lots of Tylers down there-not a hell of a lot now 'cause a lot of them moved away

But, Tate Tate's Point Creek and Tate's Point has always been a awell I think he had fifty acres cleared up on there-fifty or seventyfive acres at one time or more

But it's always been a little bit mysterious-mystery about it.

And, I'm sure, it wouldn't be any use to go look I know where that well is or I think I know-there was two wells when I moved there in nineteen hundred

And, my daddy lived there in nineteen three

And I was born in nineteen two

And I stayed there till I was till I was thirteen years old

But, I knew where the well was in the old house that we moved in when we went there and poppa tore that down and built a new one And of course he plugged the well up 
And I know where the other well was terracotta well, where it was within . . . ten feet of it; we took that well up-pulled the terracotta - the well out of the ground ... in sections and put it to another place-it was it wasn't too good a water

But I know where them two places is

But I don't think you would find anything if you was to give it a thorough search

Because, he lived for five... years or more I'd go look at his tombstone and find out

But I haven't looked at it in a many a day

And I forget-I don't think he lived too long after that

And

But he lived long enough to tell somebody or go get that money . . . after-I don't think you'd find anything in either place

But I-I knew a fellah

And his daddy . . . was one of the captains on his ships - that was Ted Midgett-his daddy . . . was captain ... of one of his ships . . . that went to the West Indies.

And, he told me his daddy told him, he lived to be eighty-five he's been dead about ten fifteen years . . . years-about fifteen years And he told me that his daddy told him these things - that this was put in-it was in-put in brass boxes down in the bottom of that well

But that-that's a . . story that there's some truth in

But you can't tell . . . how much truth there is in it; you can't tell how much truth there is in it

But it ain't all fiction-it's not all fiction

And it's not made up by me-it come to me in pieces, as I was a young fellah

And as I remember it

And I put the dates and stuff I put them together myself-I could be wrong it could have been before . . . eighteen and four but it was around that time somewhere, maybe a few years before that or a few years after; what I date that on is ... he lived to be-he was buried... in eighteen ... and forty eight-see, he was... maybe fifty sixty seventy years old I could look on his tombstone and see

But I never bothered to look-just to-date he was-I didn't-didn't know the day he was born-it's-it's on there I'm sure 
But, I never remember it didn't remember ever looking

And

But the date of his death - eighteen forty eight_-I thought for many years it's eighteen forty seven

But, the last time I visited that tombstone, somebody had rubbed that off with acid-that date-that last figure

And it was a eight instead of a . . . seven-somebody before me had rubbed that . . . over with acid, made it come up bright-him and his wife are buried side by side over there

And they're the only white people . . . was buried on Tate's Point

But there was a . . . lot of . . negroes buried over there

This narrative has two action elements, Wallace Tyler and the Baltimore waterfront fire (7b-17) and Harry Tyler's meeting with Burnside (18-31), plus a coda in the form of personal ruminations on the wells (32-43). The whole is also elaborately framed in several ways, including a prologue containing snippets of the main stories and establishing the general truth of what is to follow (1-7a), and an epilogue recapitulating the claims of truth, citing authorities and methods of reconstruction.

The narrator spends considerable time at the beginning and end of the tale giving the audience tools for interpreting what the story contains and his role in its construction and telling. He warns that the story is "fact with maybe some fiction into it or maybe some warping of the truth" (7a); at the beginning and at the end he says, "You can't tell how much truth there is in it" (44b). He also includes at start and finish a statement concerning his sources. At first he merely reports that he "got it from three generations back" (7b); he elaborates on this statement at some length at the end (42-43), with a more detailed summary of sources. At the end he also makes strong claims for the truth of at least part of the story, including the reduplicated statement "it ain't all fiction-it's not all fiction" (45a), as well as a personal disclaimer: "it's not made up by me" (45b). But although he did not make up the story in the sense that it is not all fiction, he did make it up in the sense that he put all of the pieces together $(45 \mathrm{~b})$ and through detective work added dates to the sequence of events (46). The tale is, in consequence, as much his story as it is history. What is more, it is his story because the location is personally significant and the themes associated with it are affective for him, which is why he researched the details in the first place. 
The tales of Wallace and his son Harry contain many parallels and oppositions that unite the two into one structure. Wallace escapes from Yankee fire (Baltimore is Yankee country to the people of Tidewater) and becomes rich as a result, whereas Harry is trapped by Yankee fire and loses his means of trading as a result. In both cases the fire is spoken of as a cleansing element: the waterfront fire "was cleaning the houses out" (8b), and Burnside (of all names) "started to clean up the sounds and clean up the boats" (23a). This symmetry of treacherous action born in fire and retribution visited on the son in the form of fire is patent in the second version of the tale, where the burning of the vessel marks the end of a narrative section. The themes of illgotten wealth avenged with fire also reflect classic sentiments concerning the punishments of hell and, as the fire is of Yankee origin, casts these outsiders as devil-like.

The elemental flavor of the tale continues. Water is a means of escape from the dangers of land for Wallace, but Harry fails to escape when he flees to a safe haven via water. For both men, however, water serves to keep wealth safe. Wallace tosses his gold and silver into a shallow creek, Harry puts his down a well. Thus for both water can be used to bury things (in the old sense of the word bury, meaning to keep safe), and this ethos is reinforced by the association of the water in question with earth. Gum Cove is "six to eight feet of water and mud" (14b), and a well is drilled in the earth.

Even air can be brought in to complete the elemental symmetry. Wallace "had a fair wind" (12b) and so was able to make his escape, but the wind could not help Harry. In addition, note that for Wallace the ship's masts represent safety-they carry the sails that use the fair wind-but for Harry they represent danger. The overall structure is neat. In the first half of the story fire is associated with land and is dangerous whereas masts and sea bring safety. In the second half fire is associated with the sea and is dangerous whereas lack of masts and land bring safety. In all of this activity the wind plays a dual role. The wind that is fair for Wallace is foul for the waterfront because it spreads the fire rapidly (8a), and the wind that is fair for Burnside is foul for Harry.

These oppositions and symmetries suggest that what seem to be two related actions are really one unified story, and that what look like two characters are really one metonymic (father/son) composite. The narrative begins "was a fellah buried on Tate's Point" (la) and ends "him and his wife are buried side by side over there" (49). The son's name is not clear (19), his death date is unknown (47), and his burial place is 
not mentioned. Two graves and two death dates would imply two people.

Significant also is a concern with timber and wood, which may be either helpful or harmful. On the one hand timber represents wealth. Wallace uses gold and silver to buy six thousand acres of land covered with "good timber" (3a) and uses it "to make sailing vessels" (4a). He uses these vessels, as does Harry, for trading, which in turn makes more gold and silver. Furthermore Harry tries to use trees to cover up his vessel in order to save her from the Yankees. But, of course, wood also burns: the fires that are central to the story consist of burning wood.

At the end of the tale the narrator indicates hesitantly that he is beguiled by the fact that Tate's Point has "always been a little bit mysterious." He seems reluctant to spell out this conclusion and falters in getting to it (34a). Indeed, in the second version he starts to make this point and then changes tack (2la). The revelation that Tate's Point is mysterious pulls all of the sections together in one grand mystery. What is truth and what is fiction? Which well was the money hidden in? Is there some treasure still hidden in the well? Why couldn't Tyler keep quite a hundred slaves? Why did someone rub the tombstone with acid? Why did the date on the tombstone appear to change from 1848 to 1847? When did Harry (or Hyram) die?

Part of the mystery stems from the fact that this is a story about treasure, wealth, and trading. Money is a taboo subject in normal conversation, and the act of trading has a distinctly "foreign" and distasteful air to it. Take, for example, the ethos of the general store that is the stage for most storytelling. Most local people keep accounts at the store and rarely carry or exchange money when they visit. Furthermore, the purchase of goods appears minor compared to the general social visiting that takes place at the store. Some men visit the store at night for several hours and in the process buy at most a pack of cigarettes or a soda. Foreign visitors are easily spotted: they walk into the store, select items, pay cash money on the spot, and leave with barely a word spoken. I have more to say about the conflicts between these lifestyles in the next chapter.

Because the fascination with buried treasure is taboo the narrator hedges about it while at the same time being irresistibly drawn to it. For several minutes he goes back and forth between suspecting that the treasure is still in the well and believing that it was all taken out (38-41), while also making it clear that he has never looked (although he had the opportunity). At the same time he gets vague about dates that previously he has been proud to have researched. He cannot 
remember how long after the incident Harry lived, cannot remember looking at his tombstone, and, if he did, cannot remember the date of his death.

The fate of the family and the property is appropriate. The sons continue their transactional heritage: they go off to a city to be newstyle traders. The land continues its associations as primarily of wealth value: it is bought for investment purposes by a Yankee who seldom visits (see Appendix B).

Comparison of the two versions of the tale reveals much about the mechanics of narrative structure and its relationship to performance style. It is clear that the particle "and" drives the narrative along and defines story elements. Point-by-point comparison of the two versions shows many identical or near-identical phrases following the particle. For example, compare the following pairs. In each case the first comes from version one.

And there come what they call a Baltimore waterfront fire

And there come what they call a Baltimore waterfront fire

But they caught him in the middle of the sound

And burnt him up

But they caught him on the way over

And burnt him up

Not only do these similarities help confirm that story elements defined by particles are critical narrative units, they also confirm the significance of fire. These are fixed verbal formulae that anchor the narrative.

Special particles-well, but, because, course-mark special elements. The pairs cited above begin with "but," marking the couplet as central to the action. Generally the action moves forward under a constant stream of "ands," so that other particles either create dramatic pauses initiating an element of particular significance (25a, 34a and b) or break the rhythm in more reflective passages (37-46).

At places in both versions the teller also conflates and temporarily confuses chronology or the flow of the story. Compare, for example:

And the war come in; he died; his son took over

And when the war come on with the . . . he died in eigh . . . teen . . . and forty eight

But he had a grown son that took over 
In both cases the teller, anxious to join the main action tales together, temporarily forgets to tell the audience that Wallace dies in the interim, and so he has to break the beginning of the second part to insert this information. The effect of this dovetailing is to further confuse the histories of father and son, making the unity of the whole with its symmetries and oppositions more evident. It also makes it seem as if Wallace and Harry are a single character or a single unit of some sort. Certainly as father and son they would be a single social entity in the minds of a Tidewater audience.

The teller seems to conflate story elements at points where he is trying to move action along. In both versions he has to halt the action about placing the strongboxes on the schooner to add the context element that "they dealt in gold and silver then" (version 1,9; version 2,3-4). In both versions two separable couplets are inextricably wound together in the tumbling forward of the action. The teller may also be trying to avoid explicit reference to wealth because of local taboos.

In general he prefers to move the action along and add the explanatory content parenthetically:

And, all these traders

And, Baltimore harbor was always a trading center

And he had took his gold and silver

And supposedly put it down a well, at Tate's Point, in brass boxes he had had it in brass boxes

This technique suggests that in the narrator's worldview the existential conditions are assumed and well-known and that it is action plus motivation (both the hero's and the narrator's) which lie at the core of the tale.

The delivery style is rather slow and deliberate, as marked pauses in the transcription attest. Sometimes the story hangs suspended while the teller gives careful thought to a particular element, especially dates, which, as he says, are a major contribution of his to the story (see, for example, $7 \mathrm{~b}, 46 \mathrm{~b}$, and $48 \mathrm{~b}$ ). He may also realize that he has a tendency to mistake dates, as in his mistaking the century at the beginning of the first version (7b).

In conspicuous contrast to this slow, attenuated rhythm are occasional spurts of energy in the delivery where, lack of breath notwithstanding, he is determined to get one segment out intact. For example: 
I knew where the well was in the old house that we moved in when we went there and poppa tore that down and built a new one

he couldn't keep a hundred just as soon as he got a hundred one of them would die or something would happen to one of them

These phrases are delivered without a pause and dramatically change the slow rhythm of the narrative. It is perhaps not surprising that these long phrases are associated with mysterious aspects of the story or mid-points of action.

The teller also marks key points in action with various forms of direct or incremental repetition, that is, repetition that involves small changes. To indicate the steady loading of Wallace's schooner he says:

And moved along-take the next one take the next one

Harry's brutal interrogation by the Yankees is marked by two incremental repetitions:

And when the Yankees come there to get him they knew he had gold and they knew he had silver-cause he was a trader

And, they beat him nearly 'bout to death to try to get him to tell where it was

And he wouldn't

And he didn't

The story also helps illuminate the general character of the narrative and the joint sympathies of narrator and audience. The tale has direct appeal because it is about the sea and boats, and audience and performer are watermen. Even though the tale involves treachery and retribution the narrator relies on the audience being on the side of the Tylers and against the Yankees. Tylers, whatever their origins, are local people now: neighbors and friends. Yankees are the devil incarnate. In the second version these sentiments carry over to the Yankee who ultimately bought the property for investment purposes. In many ways she represents the incursion of newcomers into the vicinity and the changes involved.

It is not necessary to repeat such detailed analysis for all the tales I recorded, but it is important to sample a range of narratives. What follows is a selection of styles and narrative structures. As in the first I have punctuated the transcriptions to follow the narrator's pauses, but 
I present each tale more like a straight prose account to make it immediately readable.

It is common for tales to move from the generally historic to the personal and to terminate with a funny tag, even if the tag is not the main thrust of the story:

The best moonshine stills there was in the world was in the Bull's Creek section of country. I've always claimed it was so much sought after because it was made out of what they call "juniper water." That was juniper timber down there, and the water was red from juniper roots. It was rainwater, and they used that rainwater, which was saturated with tannic acid from the roots of junipers. And it was a pure water. You could drink it right out of the river. You go up the river there five miles, and you could take a dipper from right overboard and drink it. You needn't worry about it. And they used that in making their mash. It was the most sought after whiskey there was in the bootleg days, was Bull's Creek liquor. It was the best. And they run it at a hundred proof. Most whiskey you get in a bottle now is ninety, eighty-five, eighty-seven. Some went down to eighty-three, I think. Ninety proof is pretty stiff. Now, Bull's Creek rye was a hundred proof. I used to drink that Bull's Creek rye. I didn't drink a whole lot of it but it was my whiskey. I don't drink any whiskey now and I never was much of a whiskey drinker. I never did like the taste of whiskey. Everything I always put in my mouth I want it to taste good, and whiskey never tasted good to me. You can mix it any way you want to. You mix it up in a Manhattan or anything you want to, and it don't make no difference to me. It just got whiskey in it. It don't taste right. Always when I put anything in my mouth I want it to taste good. That's the reason why I can't stand false teeth. They don't taste good.

Some stories end on a proverbial note, and their emphasis is on building up to a peroration on that proverb or saying:

They never used much oak [to build boats]. The oak around here, and the oak you could get-there's so many different kinds of oak. There's a white oak, and red oak and chestnut oak and swamp oak and ditch bank oak, and it won't last. But a white oak-upland oak-way away from here. If you've got logs from it, you could tell the difference when you're looking at it. But the oak all through this section is no good for boatbuilding. It'll rot in two good moonshiny nights. Two damp nights and it's rotten. But you can take real white oak, and if it'll last seven years, it'll last seventy. If it don't rot in seven years, it won't rot in seventy. That's what they always said.

Joke telling is quite uncommon, but funny stories are well-loved, especially if they turn on the teller's own misfortunes or mistakes: 
I had a job once putting up four ninety-foot poles, and I wanted to take a picture of it with the crane holding it up. I only had a forty-five-foot boom, so I was handling everything I could handle. I was overloading everything to do the job and I wanted to take a picture of it. When he got that thing straight up to set it on top of that other piling to bolt it for overhead cable, I snapped the picture. I had a camera and I went back on the other end of the barge-it was on the water-and went back to the other end of the barge and snapped a picture of the whole thing, and I got it just so. I got the piling all in there, the pole and everything. Snapped it with a Brownie. But I was looking the wrong way through the hole, and took a picture of my face. My face filled the whole camera and my cap was sitting sideways and my nose was crooked the other way. And that was the funniest-looking thing. You could look at it for about ten seconds 'fore you realized what it was. But I did take another picture. I took two or three, and the other ones I had the camera turned around right. I never knew 'till the negatives come back that I had that camera turned. It was looking right at me. You could look through either way. I snapped the picture. I got the picture right here. My son saw it and he looked at it and looked at it, and by and by he commenced to laugh and he laughed. Poppa's face filled the whole picture. Says, "That was a hell of a looking thing." My cap was sitting one way, my nose the other.

This kind of storytelling is a deeply established way of life, but it does not meet with universal approval. Telling tales is occasionally referred to as "lying," and even though the majority of tales are not lies in either the common or the folklorist's sense, the practice carries a connotation of confusing truth and fiction in a deceptive way. Note that in both versions of the first story given above the main action is framed by statements about the confusion of truth and fiction in local stories. Sitting at the store is also called "shooting the bull," "bullshitting," or "shooting the breeze," all of which carry the meanings "to lie deliberately" and "to tell stories for amusement." This local belief may also explain why "storified" sermons are frowned upon: preaching should not be confused with shooting the bull, nor should preachers be associated with those who do. As it happens, I was sitting outside the store one afternoon with a group of men when the preacher walked past, affecting not to notice us even though he was passing within a few feet and knew most of us well. But one of the more raucous men in the bunch called out to him that he should come over and get to know some of the liars sitting on the bench, because they were never likely to get to church. At this the preacher paused in his track, replied "I don't recall seeing you too often either," and walked on. 
Yet there are some similarities between preaching and storytelling style, and it may be the potential confusion in the aesthetic forms of two supposedly very different acts which leads to problems with preachers who tell too many stories. Good storytellers (and preachers) are judged on the basis of certain elements of style, particularly vocal quality. Early in my fieldwork several men in the store crowd advised me that I must certainly get to hear Ben or Roy because they have the "knack to tell a story," following this suggestion with an imitation of the vocal manner of one of them. All men identified as good storytellers had strong voices that they modulated dramatically. They also (like preachers) emphasized critical points in a tale with marked gestures. Given such similarities in mode of delivery, it seems natural that the congregation would prefer a distinct difference in narrative type between sermons and store tales.

In addition to being tagged "liars" the store crowd have a bad reputation because historically, and still to a limited extent, such men's groups planned and carried out illicit activities. In prohibition days, for example, the store was the scene of sale and consumption of bootleg whiskey. In consequence there were fights and other frownedupon behavior.

The general sense of the store as a place for "rooster" behavior is kept current by the youths. From an early age they can surreptitiously sample the sensual pleasures of whiskey, cigarettes, and chewing tobacco provided by other youths or the older men. They also have a passion of their own not shared by the older men: their cars and trucks.

Although the cars and trucks of the youths have day-to-day functions, they are sported and displayed as objects of aesthetic pleasure to the virtual exclusion of other considerations (with the possible exception of speed, which also has important aesthetic components). Exteriors are kept polished and shiny, and interiors are fitted with ornaments, decorative gadgets, and fine upholstery. Many engines and mufflers are fixed to provide bursts of loud noise, which are accentuated by gravel-throwing, tire-squealing maneuvers in the store parking lot. Such performances inevitably cause great delight among onlookers. These public displays of roosterhood are the prelude to private drag races that take place on a straight stretch of swamp road very late at night, after the state troopers have gone off duty. For most youths the combination of liquor, tobacco, and speed is an irresistible (though occasionally fatal) affective attraction.

These cars and trucks are also important for the youths' amorous 
adventures, much of their courting depending on possession of a vehicle in which to get away to some isolated spot. Young men often begin a night out with a girlfriend at the store, deliberately running the gauntlet of sly remarks by friends and older men for the sake of making it known that they are "otherwise occupied" for the evening. As a rule, though, the sexual activity of youths is taken for granted and is not the source of much comment. It is firmly expected that marriage and raising a family will calm these "dark passions." Thus those who remain single, or in some other way call attention to their continuing status as sexually available, are marked in ordinary conversation as unusually passionate.

The two major formal associations in Tidewater, Freemasons and American Legion, in large part take the place of informal associations for middle-aged adults, although the ethos differs from one to the other and from that of the store. Many adult men in the median age range belong to one or the other group, the choice depending on their personal philosophies, friendship and kinship ties, and facts of personal background. Belonging to a formal association symbolizes one's place in the community. The Masons are respectable and respected, the Legionnaires are held in low esteem.

The Legion hut is thought of as little more than a bar, even though the American Legion is a formal club with strict rules of membership, policies, meetings, and so forth. It bears all the hallmarks of disrepute: liquor, pool tables, and "uncivilized" behavior. A clear symbol of the "outlaw" status of the Legion is the evening meal served there. The fact that an evening meal is served at all is socially disruptive because it lures men away from their customary place at night, namely, at the family table. Moreover, the food served sometimes cuts across the canons of taste of the community and is deliberately advertised by members as such. In hunting season, for example, the Legion may serve barbecued raccoon, a meat considered inedible by all female cooks in town. Not only will the Legionnaires eat raccoon, but they will talk expectantly about the feast for days beforehand, adding to help confirm their social status that "coon only tastes good with whiskey."

The status of the Legion hut as a bar is accentuated by the general architecture of the building. It was formerly one of the older period 1 houses, but additions front and back have radically altered internal and external appearances. These additions, coupled with the removal of all of the ground-floor partition walls, have created one large square room, the main gathering space. It is furnished with tables and chairs, 
a pool table, and a large bar. The general ethos of the club as bar is completed by the fact that the new front and back additions have no windows, so that the room is quite dark and requires artificial light regardless of conditions outside.

Superficially the social characteristics of the store resemble those of the Legion hut, but the differences are fundamental. Most important, the membership of the Legion is made up heavily of the men of the newer families in the community, whereas the store crowd is predominantly drawn from old families. Although an outsider might consider both Legion members and the store crowd "roosters" or "pistols," the terms are used of the latter only. Such expressions embody general ambivalences that can be thought of as incorporative, that is, a man might be a pistol but he is one of "us," and we can privately joke about his scandalous behavior. When it is said that a man is "down the hut every night," there is no ambivalence involved. Finally, the Legion hut is a new institution, the present hut having been established eight years before the time of fieldwork, and represents a move on the part of newcomers to satisfy social needs. Meeting at the store, by comparison, is believed to be as old as the community itself.

The Freemasons, in complete contrast to the Legionnaires, carry with them an air of genteel respectability. Although their rituals are secret, their general comportment is socially approved. The officers make a point of attending the local churches as formal visitors several times during the year, they give to charitable organizations as well as performing good works of their own, and they are traditionally associated with Christianity.

The nature of the organization makes it inappropriate to discuss the aesthetics of the meetings and ritual in detail. What can be said, though, is that meetings are highly structured and theatrical, with a primary emphasis on obedience and loyalty to God and to the fellowship. The core of Masonry, the three degrees of the Craft, are extensive rites of passage. The rituals of these degrees are all concerned with acceptance and instruction of new members, and all formal business is focused on brotherhood and enlightenment. These rituals require special clothing, very elaborate staging, and a complex prescribed text that must be learned.

Once more this complex aesthetic behavior of men is veiled in secrecy and withdrawn from the public eye; in this case they are perhaps at their most aesthetic and their most secretive. I believe a detailed account of the rituals would be improper, but some general references to the rite of initiation to Master Mason give a feeling for 
the aesthetic intricacy of the institution. The climax of the ritual involves the theatrical enactment of the murder of the legendary architect of Solomon's temple, with the initiate playing the part of the victim and the officers of the lodge playing Solomon, the murderers, and other essential characters. The lodgeroom itself is turned into a stage for the drama, with specially made furnishings positioned to create different scenes inside and outside the temple. The play also requires appropriate props and costumes. At the end of the enactment the master of the lodge lectures the initiate on the meaning of the ritual, particularly emphasizing the nature of beauty and its relationship to the many aspects of Masonry. Indeed, the question of the nature of beauty, a paramount aesthetic question, lies at the heart of masonic teachings. The Tidewater man normally assumes an antiaesthetic public posture, and it is little wonder that such activities are conducted in secret.

Despite their private nature the Masons hold regular public functions to which they invite respected members of the larger community. The installation of a master, for example, is generally cause for public celebration, and wives and dignitaries are in conspicuous attendance. These parties, consonant with the company and the image members wish to project, are sumptuous but sober. They are produced according to local canons of good taste.

Part of the distinction between Masons and Legionnaires rests on the history of the two groups, both locally and nationally. The Masons are a venerable institution with a putative history leading back into antiquity, whereas the Legion is a relatively modern invention. To complement this distinction the Masons are well established in Tidewater, the Legion hut is quite recent. Thus the Masons draw their members primarily from the older families, and the Legion consists in large part of men from newer families. It is, therefore, not surprising that the Masons should embody the traditional values of the community and the Legion should work against them. The tensions between insiders and outsiders are once again manifest. 